\title{
Accounting
}

\section{Roadmap for the implementation of IFRS in Vietnam: Benefits and challenges}

\author{
Ngoc Thi Bui ${ }^{a}$, Oanh Thi Tu Le ${ }^{a^{*}}$ and Huy Manh Dao
}

\begin{tabular}{l}
${ }^{a}$ University of Labour and Social \\
\hline $\mathbf{C}$ H R O N I C L E \\
\hline Article history: \\
Received March 12020 \\
Received in revised format March \\
302020 \\
Accepted April 92020 \\
Available online \\
April 92020 \\
\hline Keywords: \\
Accounting in Vietnam \\
Adopting IFRS \\
Benefits \\
Difficulties \\
IFRS
\end{tabular}

\section{Introduction}

Along with the trend of globalization in cooperation and economic development, the scope of activities of investors spread around the world, accounting is no longer an intrinsic problem of each country. In 2001, the International Accounting Standards Board (IASB) issued a set of accounting principles with a new name, International Financial Reporting Standards (IFRS), focusing on presenting information on the financial statements for the international market. The purpose of the financial statements is to focus on the relationship between firms and investors regarding the information of the capital markets. This event marked a new era of global business management. The great benefits of IFRS include the improvement of the quality of the financial statements through corporate accountability, the enhanced transparency and comparability, providing users of financial statements with useful information regarding management and making investment decisions (Ashok, 2014; Siriyama $\&$ Fareedah, 2017). Although experience of other countries shows that immediate investment is needed, in the long term, the adoption of IFRS may reduce the cost of preparing financial statements for businesses, attracting resources from both domestic and foreign investments, raising capital at low costs (Odia \& Ogiedu, 2013).Since 2005, many countries have officially adopted IFRS by establishing IFRS systems suitable for their countries such as Australia, Hong Kong, European countries (Merve, 2014). Currently, IFRS is widely recognized by many countries. By 2016, there were 117 countries had started applying IFRS,

* Corresponding author. Tel.: +08496417 6633

E-mail address: oanhletu@gmail.com (Q. T. T. Le)

(C) 2020 by the authors; licensee Growing Science, Canada doi: $10.5267 /$ j.ac.2020.4.005

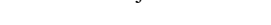


of which nearly 100 countries applied the original IFRS system. Even the United States, which has traditionally adopted its own accepted accounting principles (US GAAP), is in the process of consolidating US GAAP and IFRS (Winney et al., 2010). The African countries which apply the entire IFRS are Ghana, Botswana, Egypt, Ethiopia, Kenya, Lesoto, Malawi, Mauritius, Mozambique, Namibia, Sierra Leone, South Africa, Tanzania, Zimbabwe, Swaziland and Uganda. These countries require all listed companies, public organizations, banks and insurance companies to follow IFRS (Choi \& Nam, 2020; Owolabi \& Iyoha, 2012; Siaga, 2012). Currently, Japan allows listed companies to choose between applying Japanese standards, US GAAP or IFRS. In fact, the number of Japanese companies which choose to apply IFRS has been increasing - up to 30\% of the market capitalization now. In addition, companies which account for about $19 \%$ of market capitalization are considering the adoption of IFRS (Joshi, 2016).

Vietnam has studied and issued 26 Accounting Standards based on International Accounting Standards (IAS) during the period 2001-2005. After more than 10 years of implementation, the Vietnam Accounting Standards (VAS) helped to improve the transparency and reliability of the financial statements, providing high-quality information which is consistent with the management proficiency and peculiarities of the economy. However, in the current period, due to the pressure from the market economy and economic integration, the Vietnamese Accounting Standards system has revealed many limitations. Many standards fail to keep up with the changes of the market economy, especially in the context of strong restructuring of enterprises, financial institutions, equitization of State-owned enterprises, and the appearance of many complex financial instruments. According to the assessment of enterprises, experts and researchers, there are substantial differences between VAS and IFRS which creates barriers and reduces trust of foreign investors (Tu Oanh et al., 2019). One of the key differences between the two systems is that many items on the financial statements need to be revalued using the fair value. Therefore, the value of assets and liabilities of enterprises do not reflect the reality of the market. The failure of including important standards such as financial instruments, recognition of loss on assets makes enterprises do not have a legal basis to record losses in a timely manner. In addition, derivative financial instruments have not been widely used to prevent risks for business activities. Vietnam has a large proportion of agriculture in the economy but there is no accounting standard for agriculture. Due to the need of integrating national accounting standards with the international accounting standards, the Ministry of Finance of Vietnam is developing an accounting strategy and roadmap to complete the legal framework of accounting by 2030 (KPMG, 2018). Accordingly, Vietnam is urgently conducting research on the contents of IFRS, examining the differences between VAS and IFRS and assessing the impacts, feasibility, benefits as well as possible difficulties and challenges when applying IFRS, thereby, developing a roadmap and orientations for the adoption of IFRS in Vietnam. The adoption of IFRS can help promote business environment, build trust in domestic and international investors as IFRS is considered a global language for accounting. Therefore, Vietnam needs to have a thorough assessment and specific plans on resources to invest in the implementation of IFRS. These resources include people and finance. Thereafter, in order to continue to keep up to date with IFRS changes, Vietnam needs a long-term mechanism and resources for that mechanism. This study was conducted to collect opinions on the benefits and difficulties of business managers and accountants regarding the implementation of IFRS in Vietnam. Therefore, the main purposes of this paper are:

- Investigating the benefits and difficulties of IFRS implementation in Vietnam

- Identifying differences in the benefits and difficulties by each type of enterprise and worker

- Proposing solutions to adopt IFRS in Vietnam effectively.

\section{Literature review}

There have been many studies conducted since the 2000s on IFRS adoption in developed countries such as the US, UK, Australia and other countries such as Bangladesh, Ghana, Saudi Arabia, Greece, Africa, Jordan, Fiji, Libya, Romanian, India, Nigeria, Singapore, Malaysia and Indonesia. Research results have confirmed that the application of IFRS brings benefits to companies and stakeholders including investors, policy makers, regulators, banks (Trabelsi, 2016). Recently, a comprehensive study was conducted by European Community on IFRS application of listed firms in 2015. The research subjects are listed companies, investors, reports' users, auditing companies. The research results showed that the benefits that IFRS brings for businesses are transparency and comparability of financial statements, improvement of relevance and reliability of financial information. Accordingly, the application of IFRS improves the efficiency of the capital market - the liquidity due to attracting many investors, especially foreign investors. The confidence of investors is also increased. Overall, the study concluded that the benefits far outweigh the costs. Details are explained as follows:

\section{Benefits for enterprises (BEN)}

\section{Improving the quality of financial statements and improving the quality of corporate management}

There are many reasons why IFRS can improve the quality of financial statements. First of all, IFRS requires financial transactions to reflect in their nature rather than their names or legal forms, which will help performance of enterprises to be reflected truthfully, reliably. In other words, enterprises cannot freely hide information for specific purposes. In order to prepare and present financial statements in accordance with the IFRS, the Board of Directors needs to be more responsible, devoting 
more time for research, analysis and evaluation to reflect the nature of economic transactions (Merve et al., 2014). This helps improve the quality of management, the transparency and relevance of information. Thereby, the information gap between internal and external parties will be minimized. By adopting the IFRS, companies do not need to spend extra costs and time to explain information when requested from management agencies or partners. Therefore, enterprises can easily compare and evaluate their activities and financial situation more accurately. As a result, they can have a better understanding of customers, suppliers as well as competitors - especially competitors from countries that have adopted IFRS. Secondly, the IFRS is one condition which can ensure that firms and organizations around the world apply accounting principles consistently in the preparation of financial statements. In other words, differences in the financial statements of different counties can be minimized, thus enhancing comparability. Thereby, it can help investors reduce costs in processing accounting information, reduce differences in accounting standards between countries. In addition, the higher-quality information quality with more transparency will reduce risks for investors. Research of Merve et al. (2014), Uyar and Güngörmüş (2013), DeFond et al. (2011), Bhattacharjee (2010) was conducted in Bangladesh to assess the benefits and difficulties of implementing the IFRS. The results showed that the application of IFRS brings many benefits such as reducing capital costs, improving the quality of financial statements, and better access to global capital markets. These conclusions are also consistent with the studies of Joshi et al. (2016), Kiliçaa (2014), Ritsumeikan (2012), Choi and Meek (2011) who conducted research in developing countries such as Singapore, Malaysia and Indonesia, and studies of Cirkveni (2011) Chen et al. (2010), Gaston et al. (2010) which was conducted in European Union and the United Kingdom, or study of Alkhtani (2012) in Saudi Arabia.

\section{Attracting investment from domestic and foreign individuals and organizations}

The implementation of IFRS helps partners, investors, especially foreign investors, learn, compare and evaluate financial information in the same international standards to make appropriate decisions. When a country applies IFRS, it can reduce the political pressure on foreign investors. In fact, in order to access capital sources in the international capital market, the preparation and presentation of financial statements according to IFRS is a mandatory requirement. Moreover, the application of IFRS also brings "equality" for new or small foreign investors as they do not need to pay extra costs to "convert data". John (2018), Herath and Alsulmi (2017) proved that Nigeria and Saudi Arabia, after adopting IFRS, have changed the investment environment to allow the countries to diversify its economy, attract foreign investment and create employment opportunities for young people. Joshi et al. (2016), Ritsumeikan (2012), Choi and Meek (2011) who conducted research in Singapore, Malaysia and Indonesia; Alkhtani (2012) who carried out a study in Saudi Arabia; Dimitropoulos et al. (2013), Artikis et al. (2010) who conducted research in Greece confirmed that IFRS application makes it easier for enterprises to access domestic and international capital, and listing on foreign stock markets. Cirkveni (2011), Chen et al. (2010), Gaston et al. (2010) conducted research in European Union and the United Kingdom; Chand et al. (2010) conducted a study in Fiji. The results proved that IFRS motivates foreign investors in the acquisition and consolidation activities.

\section{Improving the effectiveness of controlling and reducing the cost of audit}

One feature of the IFRS is using fair value accounting. Therefore, the application of IFRS will help companies and users of financial statements have a more reasonable and authentic view of the current financial situation, operations and fair value of enterprises. Research results in Bangladesh, Turkey and India of Joanne et al. (2016), Merve et al. (2014), Kapoor \& Ruhela (2013), Atik (2010), showed that enterprises which have adopted IFRS had better control systems because information sources were more reliable. Ocansey and Enahoro (2014), Boateng et al. (2014), Okpala (2012) conducted research in Ghana and Nigeria, the results showed that the implementation of IRFS allows businesses to improve the efficiency of internal audit and better risks control, thus, the cost of auditing reduces more than 7.6\%. In addition, Alkhtani (2012) conducted a study in Saudi Arabia, Dimitropoulos et al. (2013), Artikis et al. (2010) conducted research in Greece, Chand et al. (2010) conducted a study in in Fiji, Joshi et al. (2016), Kiliçaa (2014), Ritsumeikan (2012), Choi and Meek (2011) conducted research in developing countries such as Singapore, Malaysia and Indonesia. The results showed that IFRS helped businesses reduce capital costs and improve stock prices.

\section{Improving competitiveness and facilitating easier accounting work}

Research of Ocansey and Enahoro (2014), Boateng et al. (2014), Okpala (2012) in enterprises in Ghana and Nigeria prove that IFRS can improve their competitiveness. Girbina et al. (2012) and Mihai et al. (2012) conducted research in Romania showed that the political pressure on multinational companies is lower when adopting IFRS than when applying national accounting standards and the adoption of IFRS creates a healthy investment environment to attract foreign companies. Joanne et al. (2016), Mulyadi et al. (2012), Bunea et al. (2012) and Bohušová \& Blašková (2011) conducted research on small and medium-sized enterprises. The results indicated that IFRS is very useful to apply in local environment for multinational companies. IFRS is considered a global language, so the application of IFRS makes it easier for professional accountants to work in different countries (Joanne et al., 2016; Mulyadi et al., 2012; Bunea et al., 2012; Bohušová \& Blašková, 2011; DeFond et al., 2011; Kim et al., 2011). Research of Joshi et al. (2016), Kiliçaa (2014), Ritsumeikan (2012), Choi and Meek (2011) which was conducted in developing countries proved the benefits of eliminating the multi-standard financial reporting system and facilitating easier work for accountants, and providing more transparent and easier to understand information (John; 2018, Adejoh; 2014, Odia; 2013). 


\section{Benefits for investors (BIN)}

The application of IFRS can create many favorable conditions and reliable basis for investors. The financial statements prepared under IFRS provide comprehensive, relevant, and timely information, therefore, investors have lots of information about the capital market. The financial statements formatted in a consistent format can eliminate differences in accounting standards of different countries, thus, the information provided can ensure comparability, helping investors reduce costs in processing accounting information. In addition, the higher-quality and transparent information can reduce risks for investors. Boateng et al. (2014) conducted research on the benefits and challenges of applying IFRS in Ghana through in-depth interviews with 18 accountants of listed companies. The research pointed out that IFRS provides better, reliable information for investors to make decisions. In addition, studies of different authors which were conducted in different countries, different time periods, different contexts provide the same conclusions. Specifically, Joshi et al. (2016), Ritsumeikan (2012), Choi and Meek (2011) implemented research in developing countries such as Singapore, Malaysia and Indonesia; Cirkveni (2011), Chen et al. (2010) and Gaston et al. (2010) conducted research in European Union and the United Kingdom. They all agreed that the application of IFRS increases investors' confidence. The research of John (2018), Herath \& Alsulmi (2017), Alkhtani (2012) in Nigeria and Saudi Arabia; Dimitropoulos et al. (2013), the study of Artikis et al. (2010) in Greece; the study of Chand et al. (2010) in Fiji; the study of Kapoor \& Ruhela (2013) in India, the studies of Girbina et al. (2012) and Mihai et al. (2012) in Romania proved that financial statements which were published promptly and honestly, help investors have a better basis to compare, evaluate and select better investment alternatives.

\section{Benefits for policy makers (BPO)}

For policymakers, the adoption of IFRS makes the capital market more consolidated and efficient, promotes cross-border investment and better controlling of information for the purpose of decision making. For industry authorities, the adoption of IFRS can lead to improvement of regulatory supervision and enforcement, higher standards of financial disclosure, better information for market participants, attracting and monitoring the list of foreign companies better. The study of John (2018) in Nigeria and research of Herath and Alsulmi (2017), Joshi et al. (2016), Ritsumeikan (2012), Choi and Meek (2011) in developing countries such as Singapore, Malaysia and Indonesia, and research of Kapoor and Ruhela (2013) in India confirmed that IFRS brings better information for controlling and decision making.

\section{Promoting the development of the stock market}

Ashok (2014) examined experience of countries which have applied IFRS and found that listed companies will benefit from economic integration such as accessing domestic and foreign capital sources, maintaining competitiveness and sustainable development. On the other hand, through the experience of applying IFRS in the world, the transparency and reliability of information of listed companies and the stock market have been improved which increases trust among investors, especially foreign investors. In the study on the impact of IFRS in Europe, Asia and Africa, the cost of capital of European companies is estimated to improve by $1 \%$. Although the number is relatively small, the absolute number is very large because it is calculated by the amount of money/total market value of all shares of these companies. In Asia, the study of Joshi et al. (2016), Ritsumeikan (2012), Choi and Meek (2011) conducted in developing countries such as Singapore, Malaysia and Indonesia showed the relationship between financial statements and stock prices and found that stock prices increased significantly after these companies applied IFRS.

\section{Attracting and developing foreign investment}

The application of IFRS of each country demonstrates the strong commitment of the government in protecting investors and creating a healthy business environment for the goal of sustainable development. Therefore, it attracts resources from abroad, enabling the country to raise capital at low costs because companies which apply IFRS can successfully get listed and raise capital on the international market. Research of John (2018), Herath and Alsulmi (2017), Alkhtani (2012), Dimitropoulos et al. (2013) and Artikis et al. (2010) in Nigeria, Saudi Arabia and Greece demonstrated that foreign investment increases 15.3\% which further strengthens the confidence of existing investors and thereby contributing to maintaining the growth rate of economy which is the foundation for future development.

\section{Creating opportunities for enterprises to access international capital at a reasonable cost}

Since IFRS is widely accepted across the globe, it is the language that international investors can understand and accept. In many cases, due to a lack of understanding of national accounting standards, foreign investors often have a more cautious attitude towards financial statements prepared according to accounting standards of each country. Whereby, they often apply a certain discount when valuating stocks issued by companies who do not prepare their financial statements according to IFRS. For foreign investors, the lack of financial information in accordance with IFRS can increase the risks of the loan and therefore, they tend to apply a higher interest rate or refuse to lend money if the borrower does not have a financial statement prepared under IFRS. Boateng et al. (2014), Okpala (2012) investigated the ability to attract loans of enterprises in Ghana and Nigeria; Girbina et al. (2012). Mihai et al. (2012) studied enterprises in Romania and showed that applying IFRS has created many 
opportunities for businesses to be able to borrow capital from the international market at low costs.

\section{Strengthening the support from IASB}

Countries which adopt the IFRS can reduce costs of setting national accounting standards and also receive IASB's active support in exchanging information, updating on-going projects and impact of such projects on businesses. At the same time, countries can contribute their input in the revision of the IFRS (Joanne et al., 2016; Judge et al., 2010; Sun et al., 2011; Shima \& Yang, 2012; Hail et al., 2020).

\section{Benefits for authorities (BAU)}

One of the most obvious benefits that IFRS brings to the management agencies is that it provides lots of useful information for management decisions, administration, risks control, and decisions related to inspection, examination and supervision of the authorities. IFRS requires corporations to increase accountability, improve transparency of financial statements and comparability among companies. In addition, it requires financial transactions to be objectively and truthfully reflected according to standards of financial disclosure. Therefore, information on performance of companies is relatively reliable which is useful for the market participants (DeFond et al., 2011, Bhattacharjee, 2010). Furthermore, IFRS is proved to improve the monitoring and enforcement of regulations (John, 2018; Herath \& Alsulmi, 2017), attract foreign investment to the domestic market (Kapoor, 2013; Dimitropoulos et al., 2013; Artikis et al., 2010; Chand et al., 2010).

\section{Challenges of the implementation of IFRS (CHA)}

IFRS has been applied in many countries as an important tool to standardize international accounting principles and financial statements in both developed and developing countries. In other words, the benefits of IFRS are substantial. However, when implementing the IFRS, many countries face many difficulties such as costs, human resources, market, legal, and technical issues.

Cost issues: Costs receive much attention from developing countries when implementing IFRS. Research of Samaha \& Khlif (2016), Oghogho et al. (2016) in developing countries, and study of Abd (2014) in Middle Eastern countries provided that the first difficulty related to cost issues is translating standards into national languages. Other costs include human resource training, investment in infrastructure and changing software system, testing, and implementation. Research of Xinyun et al. (2017), Young \& Zeng (2015), Ashok (2014, Jones \& Finley (2011), Oluku \& Ojeka (2011), Zéghal et al. (2011), Winney et al. (2010), Artikis et al. (2010) assessed difficulties in applying IFRS including costs, time, complexity required for the changes. Empirical research of Nerudova and Bohusova (2008) showed that the application of IFRS in small and medium-sized enterprises in the Czech Republic faces many difficulties due to the small scale and some inappropriate contents of IFRS. Agyei-Mensah (2013), Aboagye-Otchere et al. (2012) examined SMEs in Ghana and found that they could not apply IFRS in the first place since they were limited by size, operating time and legal form. In addition, costs of conversion and handling incident, and repairing costs is a matter of concern for companies in the transition to IFRS.

Human resources issues: The training of accountants and financial experts regarding IFRS receives much attention from researchers in Hungary (Artikis et al., 2010, Jones \& Finley, 2011). Research of John (2018) in Nigeria showed that accountants' proficiency is not enough to meet the requirements of IFRS as they do not have a thorough understanding of IFRS to read or apply IFRS in practices. He stated that although facing many challenges, Nigeria can overcome such difficulties by training professional accountants, raising the awareness of managers and scientists about IFRS to reduce the knowledge gap and providing sufficient resources to support the sustainable implementation of IFRS. Samaha \& Khlif (2016), Oghogho et al. (2016) conducted research in developing countries, Abd (2014) investigated difficulties when applying IFRS in Middle East countries, Mohamed (2014) carried out a study in Libya, Owolabi (2012), Siaga (2012) conducted research in Africa. They supposed that one of the barriers in implementing IFRS is the ability to understand and apply IFRS of the current accounting team as the accountants need to have knowledge of other fields to help analyze and record transactions according to their nature. Moreover, some of the terms used in IFRS are relatively complicated, specialized and very difficult to translate in other languages. Finally, studies of Siam and Rahahleh (2010) in Jordan, study of Mohamed (2014) in Libya, and study of Monisola (2013) in Nigeria provided that the IFRS is relatively complicated and confusing to users, even for users of developed economies. Currently, the accounting teams of enterprises have not been officially trained about the IFRS. In addition, IFRS requires accountants to have a deep understanding of the operations of enterprises, capture and analyze information to be able to record transactions according to their nature. Proper application of accounting methods and the requirements of presentation and disclosure under IFRS may require more detailed information - accordingly, this may result in an increase in work volume and training experts about information technology.

Legal issues: The accounting systems of many countries are affected by tax regulations and financial laws. If IFRS is implemented, there are vast differences between accounting and tax regulations (Samaha \& Khlif, 2016; Oghogho et al., 2016). It was agreed that the current legal system needs to be modified to create a facilitating environment for IFRS (Mohamed, 2014; Owolabi, 2012; Siaga, 2012; Siam \& Rahahleh, 2010). Xinyun et al. (2017), Young and Zeng (2015), Zakari (2014) pointed out difficulties when IFRS are regularly changed and updated annually. Ashok (2014), Jones and Finley (2011) assessed the 
difficulties related to the law as IFRS requires strict compliance.

Market issues: Raoudha (2016), Jones \& Finley, 2011, Artikis et al., 2010 proved that since IFRS requires the presentation of the assets and liabilities of enterprises at market value at the time of reporting, the market needs to be relatively developed be able to provide reliable information. Research in undeveloped and developing countries of Samaha and Khlif (2016), Oghogho et al. (2016) showed that the capital market and financial market were not developed, some financial instruments such as convertible bonds, derivatives, preferred stocks have not been widely traded. Therefore, most companies had not had experience in conducting recording transactions in such contexts. The market is in the stage of formation and development, so it is impossible to provide reliable information about the value since the factors for determining fair value are not available. In addition, the determination of fair value of markets varies widely, and the applications of IFRS among countries are also different (some countries fully or partially applied), making it difficult to compare different financial statements. IFRS requires some complex techniques and subjective assessments such as: Making estimates of fair value when there is no market price, recoverable values, recognition of loss of assets and goodwill, determining the present value of future cash flows, so basically IFRS is only suitable for large-scale enterprises with professional accounting staff.

\section{Methodology}

In the literature review, the study summarized the research of countries from 2010 to the present. This study uses the scales of previous studies and investigates 5 factors: (i) The benefits for enterprises; (ii) The benefits for investors; (iii) The benefits for policy makers; (iv) The benefits for authorities; and (v) The difficulties in applying IFRS.

\section{Table 1}

Measurement scales

\begin{tabular}{|c|c|c|c|}
\hline Factor & Code & Scale (Variable) & Sources \\
\hline \multicolumn{4}{|c|}{ Benefits for enterprises (BEN) } \\
\hline \multirow{4}{*}{$\begin{array}{l}\text { Improving the quality of } \\
\text { financial statements and } \\
\text { corporate management } \\
\text { (BEN1) }\end{array}$} & BEN11 & $\begin{array}{llll}\text { Increasing enterprises' responsibility } & \text { to } \\
\text { information on financial statements } & & \end{array}$ & Merve et al. (2014) \\
\hline & BEN12 & $\begin{array}{l}\text { Improving the quality of financial statements to be more } \\
\text { reliable and truthful }\end{array}$ & $\begin{array}{l}\text { Uyar \& Güngörmüss (2013); DeFond et al. } \\
\text { (2011); Bhattacharjee (2010) }\end{array}$ \\
\hline & BEN13 & $\begin{array}{l}\text { Easier comparison of financial information among } \\
\text { domestic and foreign enterprises }\end{array}$ & $\begin{array}{l}\text { Chen et al. (2010); Gaston et al. (2010); } \\
\text { Alkhtani (2012) }\end{array}$ \\
\hline & BEN14 & Providing a basis for managers to make decisions & $\begin{array}{l}\text { Joshi et al. (2016); Ritsumeikan (2012); Choi } \\
\text { and Meek (2011) }\end{array}$ \\
\hline \multirow{4}{*}{$\begin{array}{l}\text { Attracting domestic and } \\
\text { foreign investment } \\
\text { (BEN2) }\end{array}$} & BEN21 & Reducing political pressure on foreign investors & $\begin{array}{l}\text { Alkhtani (2012); Dimitropoulos et al. (2013); } \\
\text { Artikis et al. (2010) }\end{array}$ \\
\hline & BEN22 & $\begin{array}{l}\text { Better access to foreign capital in an equal and easy } \\
\text { manner }\end{array}$ & John (2018); Herath \& Alsulmi (2017) \\
\hline & BEN23 & Facilitating the listing on foreign stock markets & $\begin{array}{l}\text { Joshi et al. (2016); Ritsumeikan (2012); Choi } \\
\text { and Meek (2011) }\end{array}$ \\
\hline & BEN24 & $\begin{array}{l}\text { Promoting foreign investors in merger and acquisition } \\
\text { activities }\end{array}$ & $\begin{array}{l}\text { Chen et al. (2010); Gaston et al. (2010); Chand } \\
\text { et al. (2010) }\end{array}$ \\
\hline \multirow{4}{*}{$\begin{array}{l}\text { Improving the } \\
\text { effectiveness of control } \\
\text { and stock prices } \\
(\mathrm{BEN} 3)\end{array}$} & BEN31 & Better control of sources of reliable information & $\begin{array}{l}\text { Merve et al. (2014); Atik (2010); Joanne et al. } \\
\text { (2016) }\end{array}$ \\
\hline & BEN32 & Improving the quality of internal audits & $\begin{array}{l}\text { Ocansey \& Enahoro (2014), Boateng et al. } \\
\text { (2014), Okpala (2012) }\end{array}$ \\
\hline & BEN33 & Reducing costs of raising capital and audit costs & $\begin{array}{l}\text { Joshi et al. (2016), Ritsumeikan (2012), Choi } \\
\text { and Meek (2011) }\end{array}$ \\
\hline & BEN34 & Increasing stock prices & $\begin{array}{l}\text { Alkhtani (2012), Dimitropoulos et al. (2013), } \\
\text { Artikis et al. (2010) }\end{array}$ \\
\hline \multirow{4}{*}{$\begin{array}{l}\text { Improving } \\
\text { competitiveness and } \\
\text { facilitating easier } \\
\text { accounting work } \\
\text { (BEN4) }\end{array}$} & BEN41 & Improving enterprises' competitiveness & $\begin{array}{l}\text { Ocansey \& Enahoro (2014), Boateng et al. } \\
\text { (2014), Okpala (2012) }\end{array}$ \\
\hline & BEN42 & Creating a healthy business environment for enterprises & Mihai et al (2012) \\
\hline & BEN43 & $\begin{array}{l}\text { Eliminating the multi-standard financial reporting } \\
\text { system and facilitating easier work for accountants }\end{array}$ & $\begin{array}{l}\text { Joanne et al. (2016), Mulyadi et al. (2012), } \\
\text { Bunea et al. (2012), Bohušová \& Blašková } \\
\text { (2011) }\end{array}$ \\
\hline & BEN44 & Facilitating professional accounting work internationally & $\begin{array}{l}\text { Joanne et al. (2016), Mulyadi et al. (2012), } \\
\text { Bunea et al. (2012), Bohušová \& Blašková } \\
\text { (2011), DeFond et al. (2011), Kim et al. } \\
\text { (2011); Joshi et al. (2016), Ritsumeikan } \\
\text { (2012), Choi et al. (2011) }\end{array}$ \\
\hline \multicolumn{4}{|l|}{ Benefits for investors (BIN) } \\
\hline & BIN1 & Providing reliable a basis for decision making & Boateng et al. (2014) \\
\hline & BIN2 & Enhancing investors' confidence & $\begin{array}{l}\text { Joshi et al. (2016), Ritsumeikan (2012), Choi } \\
\text { and Meek (2011) }\end{array}$ \\
\hline & BIN3 & Reducing risks for investors & Chen et al. (2010) và Gaston et al. (2010) \\
\hline & BIN4 & $\begin{array}{l}\text { Providing a basis for comparison and evaluation to } \\
\text { select better investment opportunities }\end{array}$ & $\begin{array}{l}\text { John (2018), Herath \& Alsulmi (2017), } \\
\text { Alkhtani (2012) }\end{array}$ \\
\hline
\end{tabular}


Table 1

Measurement scales (Continued)

Benefits for policy makers (BPO)

\begin{tabular}{|c|c|c|c|}
\hline & BPO1 & Promoting the development of the stock market & $\begin{array}{l}\text { Ashok (2014), Joshi h et al. (2016), } \\
\text { Ritsumeikan (2012), Choi and Meek (2011) }\end{array}$ \\
\hline & $\mathrm{BPO} 2$ & Attracting foreign investment & $\begin{array}{l}\text { John (2018), Herath \& Alsulmi (2017), } \\
\text { Alkhtani (2012), Dimitropoulos et al. (2013), } \\
\text { Artikis et al. (2010) }\end{array}$ \\
\hline & $\mathrm{BPO} 3$ & $\begin{array}{l}\text { Creating many opportunities for enterprises to access } \\
\text { international capital at reasonable costs }\end{array}$ & $\begin{array}{l}\text { Boateng et al. (2014), Okpala (2012, Girbina } \\
\text { et al. (2012). Mihai et al (2012) }\end{array}$ \\
\hline & BPO4 & Strengthening the support of IASB & Joanne et al. (2016) \\
\hline \multicolumn{4}{|c|}{ Benefits for authorities (BAU) } \\
\hline & BAU1 & Raising standards of financial disclosure & DeFond et al. (2011), Bhattacharjee (2010) \\
\hline & BAU2 & Providing better information for market participants & DeFond et al. (2011), Bhattacharjee (2010) \\
\hline & BAU3 & Improving enforcement of the law & Artikis et al. (2010), Chand et al. (2010) \\
\hline & BAU4 & Attracting foreign investment for the domestic market & $\begin{array}{l}\text { Kapoor (2013), Dimitropoulos et al. (2013), } \\
\text { Artikis et al. (2010), Chand et al. (2010) }\end{array}$ \\
\hline \multicolumn{4}{|c|}{ CHA: challenges of the implementation of IFRS } \\
\hline \multirow{4}{*}{$\begin{array}{l}\text { Cost issues } \\
\text { (CHA1) }\end{array}$} & CHA11 & Translation costs of IFRS & $\begin{array}{l}\text { Samaha \& Khlif (2016), Oghogho et al. } \\
\text { (2016), Abd (2014) }\end{array}$ \\
\hline & CHA12 & $\begin{array}{l}\text { Training costs for human resources including } \\
\text { accountants, directors, experts, lecturers and students }\end{array}$ & $\begin{array}{l}\text { Xinyun et al. (2017), Young \& Zeng (2015), } \\
\text { Ashok (2014), Jones \& Finley (2011) }\end{array}$ \\
\hline & CHA13 & $\begin{array}{l}\text { Investment in infrastructure, software systems, testing, } \\
\text { and implementation }\end{array}$ & $\begin{array}{l}\text { Agyei-Mensah (2013), Aboagye-Otchere et al. } \\
\text { (2012), Oluku, \& Ojeka (2011), Zéghal et al. } \\
\text { (2011) }\end{array}$ \\
\hline & CHA14 & $\begin{array}{l}\text { Costs of conversion, handling incidents and the } \\
\text { resolutions thereof }\end{array}$ & $\begin{array}{l}\text { Nerudova \& Bohusova (2008); Winney et al. } \\
(2010) \text {, Artikis et al. (2010) }\end{array}$ \\
\hline \multirow{4}{*}{$\begin{array}{l}\text { Human resources issues } \\
\text { (CHA2) }\end{array}$} & CHA21 & $\begin{array}{l}\text { Accountants do not have a thorough understanding of } \\
\text { IFRS to read, interpret, and apply IFRS in practice. }\end{array}$ & $\begin{array}{l}\text { Artikis et al. (2010), Jones \& Finley (2011), } \\
\text { John (2018) }\end{array}$ \\
\hline & CHA22 & $\begin{array}{l}\text { Accountants need to have knowledge of other fields to } \\
\text { analyze and record economic transactions according to } \\
\text { their nature. }\end{array}$ & $\begin{array}{l}\text { Mohamed (2014), Owolabi (2012), Siaga } \\
\text { (2012), Samaha \& Khlif (2016), Oghogho et } \\
\text { al. (2016) }\end{array}$ \\
\hline & CHA23 & $\begin{array}{l}\text { It is difficult to retain accountants who have proficiency } \\
\text { and experience in IFRS. }\end{array}$ & $\begin{array}{l}\text { Siam \& Rahahleh (2010), Mohamed (2014), } \\
\text { Monisola (2013) }\end{array}$ \\
\hline & CHA24 & $\begin{array}{l}\text { The workforce including accountants, directors, and } \\
\text { experts need to acquire knowledge of financial } \\
\text { statements according to IFRS. }\end{array}$ & Owolabi (2012), Siaga (2012) \\
\hline \multirow{4}{*}{$\begin{array}{l}\text { Legal issues } \\
\text { (CHA3) }\end{array}$} & CHA31 & Differences between accounting and tax & Samaha \& Khlif (2016), Oghogho et al. (2016) \\
\hline & CHA32 & $\begin{array}{l}\text { The legal system needs to be modified to create a } \\
\text { facilitating environment for IFRS application. }\end{array}$ & $\begin{array}{l}\text { Mohamed (2014), Owolabi (2012), Siaga } \\
\text { (2012), Siam \& Rahahleh (2010) }\end{array}$ \\
\hline & CHA33 & IFRS may be changed and updated annually. & $\begin{array}{l}\text { Xinyun et al. (2017), Young \& Zeng (2015), } \\
\text { Zakari (2014) }\end{array}$ \\
\hline & CHA34 & IFRS requires strict compliance and enforcement. & Ashok (2014, Jones \& Finley (2011) \\
\hline Market issues & CHA41 & $\begin{array}{l}\text { The capital markets and financial markets are } \\
\text { developing. }\end{array}$ & Samaha \& Khlif (2016), Oghogho et al. (2016) \\
\hline \multirow[t]{3}{*}{ (CHA4) } & CHA42 & $\begin{array}{l}\text { It is difficult to get reliable information about the fair } \\
\text { value of items. }\end{array}$ & Raoudha (2016), Jones \& Finley (2011) \\
\hline & CHA43 & Many transactions do not have identified markets. & Artikis et al. (2010) \\
\hline & $\mathrm{CHA} 44$ & The markets are not synchronized. & $\begin{array}{l}\text { Samaha \& Khlif (2016), Oghogho et al. } \\
\text { (2016), Jones \& Finley ( 2011) }\end{array}$ \\
\hline
\end{tabular}

The study was conducted through sending questionnaires to enterprises in 2019 to collect data from two groups: accountants and managers with 100 questionnaires sent to each group. The role of the accountants and the chief accountants comes from the responsibility of preparing the financial statements of the enterprise, while the role of managers lies in using the information and taking legal responsibility for the information published by the enterprises. Both groups have equal roles in this study. The official questionnaire includes multiple choice questions, open-ended questions, and questions using 5-point likert scale (1Strongly disagree; 5- Strongly agree). The questionnaire is divided into 2 main sections, including: (i) The benefits of IFRS implementation and (ii) The difficulties in implementing IFRS. In addition, the questionnaire includes questions about the roadmap of the implementation of IFRS in Vietnam, personal information of respondents and surveyed enterprises. The total number of questionnaires distributed was 200, the locations of this study included the North and the South of Vietnam, types of businesses participating in the survey include joint stock companies, limited liability companies, and privately-owned companies. The number of answers received was 156 , accounting for $78 \%$. After eliminating blank and random answers, the total number of valid answers was 119. Descriptive statistics of characteristics of respondents are shown in Fig.1. Out of 119 respondents, the majority of them were female ( 89 people, accounting for $74.8 \%$ ). Regarding age, most respondents were over 45 (56 people; $47.1 \%)$. Regarding the level of education, most of them had a bachelor's degree $(63 ; 52.9 \%)$, the rest had a master degree $(56 ; 47.1 \%)$. 


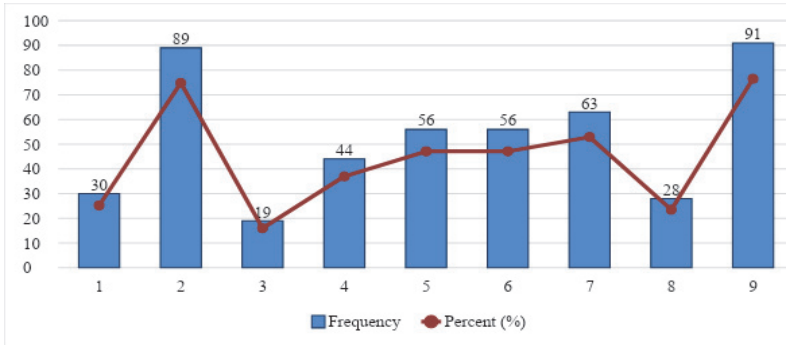

Fig. 1. Characteristics of respondents

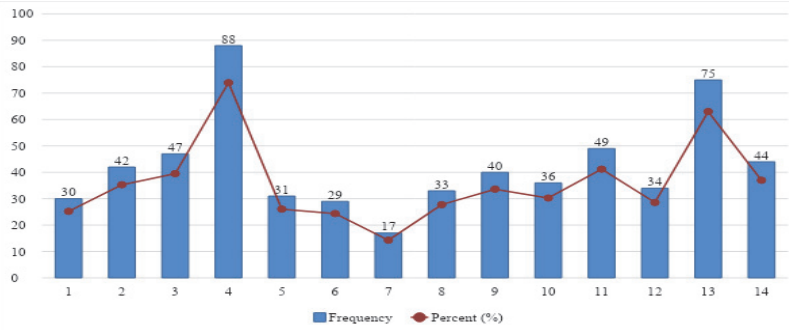

Fig. 2. Characteristics of enterprises participating in this study

(Source: Authors synthesized on the basis of research results)

Regarding positions, the majority of respondents were accountants $(91 ; 76.5 \%)$. The sample shows specific characteristics of accounting personnel in Vietnamese companies. Firstly, accounting jobs attract more women than men. Ages of accountants in enterprises vary. However, chief accountants are often more than 45 years old. Since they are directly responsible for setting up the accounting system and financial statements of the companies, they might be interested in using IFRS. Regarding the level of education, there is not much of a difference between the number of respondents who hold a bachelor's degree and the number of respondents who hold a master's degree, for they are both popular qualifications for the accounting profession in Vietnam. Fig. 2 shows the characteristics of the businesses surveyed. Firstly, in terms of length of operation, most enterprises had been operating for more than 20 years $(47 ; 39.5 \%)$, which is followed by enterprises which had been operating for 10-20 years (42; $35.3 \%$ ), and the number of enterprises which had been operating for less than 10 years was the smallest. Secondly, in terms of geographic area, the majority of enterprises were located in the North ( 88 enterprises; $73.95 \%$ ). In this sample, the number of enterprises in the North was almost as 3 times as the number of enterprises in the South because the capital of Vietnam is in the North which is also where the research team was located. Thirdly, regarding the type of enterprises, most enterprises were joint stock enterprises $(40 ; 33.6 \%)$, the number of limited liability companies and foreign-invested enterprises were quite similar (27.7\% and 24.4\%), and the number of private enterprises was the smallest. This is also the typical proportion of enterprises in Vietnam in general in which most enterprises are joint stock companies and there are few private enterprises. Fourthly, regarding business sector, most enterprises were in trading and service sector, the remaining are manufacturing or mixed business. Fifthly, in terms of scale, small and medium-sized enterprises with less than 300 employees accounted for the largest proportion in the sample $(75 ; 63 \%)$. The distribution of enterprises by the size of the sample also shows the characteristics of enterprises in developing countries with $97 \%$ of small and medium-sized enterprises.

\section{Results and discussion}

\subsection{Evaluation of the implementation of IFRS}

\section{IFRS application roadmap in Vietnam}

Regarding IFRS application roadmap in Vietnam, the majority of experts believe that Vietnam can apply IFRS in 3 to 5 years (accounting for $45.65 \%$ ), followed by 5 to 10 years (accounting for 38.04\%). Apart from that, some believe the application of IFRS in Vietnam are close in the coming time (less than 3 years) and others are pessimistic about the time when Vietnam will apply IFRS.

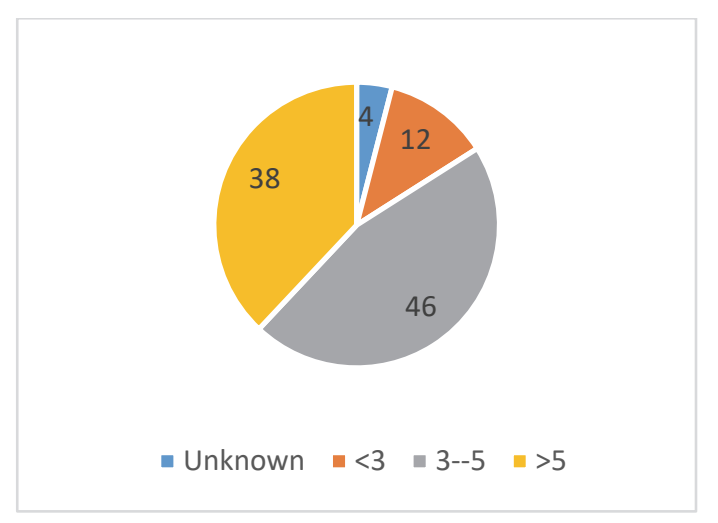

Fig. 3. IFRS application roadmap in Vietnam

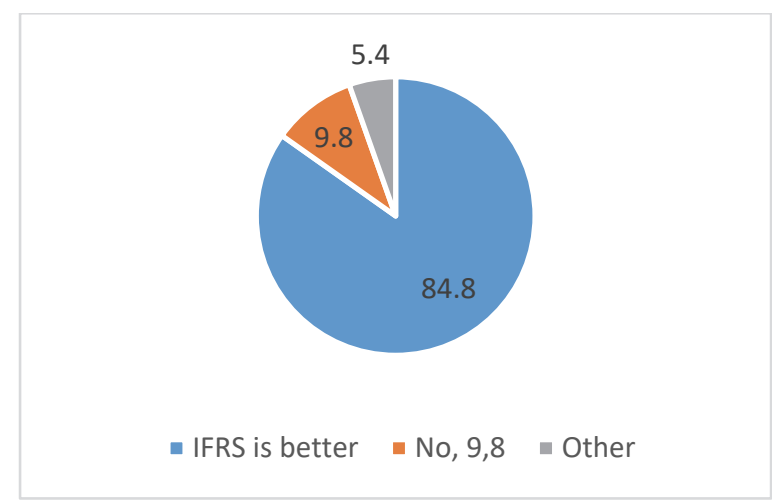

Fig. 4. IFRS are better than VAS

(Source: Authors synthesized on the basis of research results) 
The majority of respondents said that the application of IFRS would be better than applying current accounting standards (accounting for 84.8\%). This result is consistent with the interview results of experts. Specifically, experts believe that IFRS ensure the comparability, transparency and require strict adherence to regulations on information disclosure and professional ethics. Therefore, applying IFRS will improve the quality of information on financial statements; attract investment and enhance business cooperation opportunities, competitiveness and international economic integration; improve the quality of information, quality of accountants and business efficiency, rapidly integrate into international accounting standards. On the contrary, a few people disagree with the above point of view, others have different opinions. Specifically, whether or not IFRS application is better depends on the subjects of application, conditions of application as well as the legal infrastructure of Vietnam.

\subsection{The benefits and challenges of the implementation of IFRS}

Table 2a

General evaluation of the benefits and challenges of the implementation of IFRS

\begin{tabular}{|c|c|c|c|c|c|c|c|}
\hline Cod & $\mathrm{N}$ & Mean & Std. Deviation & Skewness & Std. Error of Skewness & Kurtosis & Std. Error of Kurtosis \\
\hline BEN & 119 & 3.8347 & .47897 & -.034 & .222 & 1.023 & .440 \\
\hline BIN & 119 & 3.9454 & .53683 & . 127 & .222 & .908 & .440 \\
\hline BPO & 119 & 3.9731 & .56744 & -.024 & .222 & .023 & .440 \\
\hline BAU & 119 & 4.0000 & .53867 & .032 & .222 & .499 & .440 \\
\hline CHA & 119 & 3.9619 & .41423 & .603 & .222 & .859 & .440 \\
\hline
\end{tabular}

(Source: Authors synthesized on the basis of research results)

Table 2b

Detailed evaluation of the benefits and challenges of the implementation of IFRS

\begin{tabular}{|c|c|c|c|c|c|c|}
\hline \multirow{2}{*}{\multicolumn{2}{|c|}{ No. Cod }} & \multicolumn{4}{|c|}{ Benefits } & \multirow{2}{*}{$\begin{array}{c}\text { Difficulties } \\
\text { CHA }\end{array}$} \\
\hline & & BEN & BIN & BPO & BAU & \\
\hline & 1 & 4.1645 & 4.1236 & 3.8761 & 4.0990 & 3.9874 \\
\hline & 2 & 4.0050 & 4.2251 & 4.1235 & 4.3190 & 4.3215 \\
\hline & 3 & 3.6859 & 3.8956 & 3.8956 & 3.8945 & 3.8956 \\
\hline & 4 & 3.4834 & 3.5373 & 3.9972 & 3.6875 & 4.3511 \\
\hline Average & & 3.8347 & 3.9454 & 3.9731 & 4.0000 & 4.1389 \\
\hline
\end{tabular}

(Source: Authors synthesized on the basis of research results)

The overall assessment of the benefits and difficulties of the implementation of IFRS in Table 2a had mean values ranging from 3.83 to 4.00 . The assessment of the benefits for managers had the highest mean value (mean 4.00), the benefits for enterprises had the lowest mean value (mean 3.83). These values do not show a high consensus of respondents but they show the consensus on the evaluation criteria. The standard deviations of all factors ranged from 0.41 to 0.56 . The value of standard deviation proves that there is not much of a difference in the assessments of respondents on the factors. The skewness of 5 factors BEN, BIN, $\mathrm{BPO}, \mathrm{BAU}, \mathrm{CHA}$ were relatively low (0.22), so the assessments are symmetrical. The detailed assessment of benefits and difficulties for each factor in Table $2 \mathrm{~b}$ shows that the level of fluctuation of the benefits for enterprises (BEN) was the highest, from 3.4 to 4.1, the level of fluctuation of the benefits for policy makers (BAU) was the lowest, from 3.7 to 4.1 . This shows that there is not much of a difference in the assessment on factors and each factor. Details of each factor are explained as follows:

Benefit for enterprises (BEN) included 4 items with a mean value of 3.83. Particularly, improving the quality of financial statements and the quality of corporate management (BEN1) had the highest mean value of 4.16, which was followed by the attracting investment of domestic and foreign individuals and organizations (BEN2) which had a mean value of 4.00, and finally improving competitiveness and facilitating accounting work (BEN4) had a mean value of 3.48. In general, these values show the agreement of respondents with the benefits that enterprises can gain from the implementation of IFRS. Benefits for investors (BIN) had a mean value of 3.94, which was higher than the mean value of benefits for enterprises. Particularly, the benefit for investors is to increase the investors' confidence in the financial statements (BIN2) had the highest mean value of 4.22. Providing a basis for comparison and evaluation to choose better investment opportunities (BIN4) had the smallest mean value of 3.53 but it is still within the agreement side of the scale. Benefits for policy makers (BPO) is measured by four items: (i) Promoting the development of the stock market; (ii) Attracting and developing foreign investment; (iii) Creating many opportunities for enterprises to access international capital at reasonable costs; (iv) Strengthen the support of IASB, with mean values of 3.88; $4.12 ; 3.90 ; 4.00$ respectively. The results show that this factor received the highest consensus of the respondents. BPO2 which is attracting and developing foreign investment had the highest mean value of 4.12 , while promoting the development of the stock market had the smallest value of 3.88. Benefits for authorities (BAU) are assessed by four variables: Higher standards of financial disclosure $($ mean $=4.09)$, Better information for market participants (mean $=4.31$ ), Improving supervision and enforcement of the law (mean $=3.89$ ), Attracting foreign investment for the domestic market (mean $=3.68)$. Thus, the variable 
better information for market participants had the highest mean value of 4.31. The challenges of the implementation of IFRS are measured by four variables: cost, human resources, market, and legal issues. Particular, challenges related to the market (CHA4) had the highest mean value of 4.35, which was followed by human resources issues. Namely, accountants do not have a thorough understanding of IFRS to read, interpret, and apply IFRS in practice, accountants need to have knowledge of other fields to analyze and record economic transactions according to their nature, it is difficult to retain accountants who have proficiency and experience in IFRS, the personnel system including accountants, directors, and experts need to acquire knowledge of financial statements according to IFRS.

\subsection{Comparison of groups of respondents}

\section{Comparison based on demographic characteristics}

To investigate whether there is a difference between the benefits and challenges of the implementation of IFRS in Vietnam by demographic characteristics of respondents, the selected criteria are gender, age, level of education, job position. The results are shown in Fig. 5.

5a. Gender

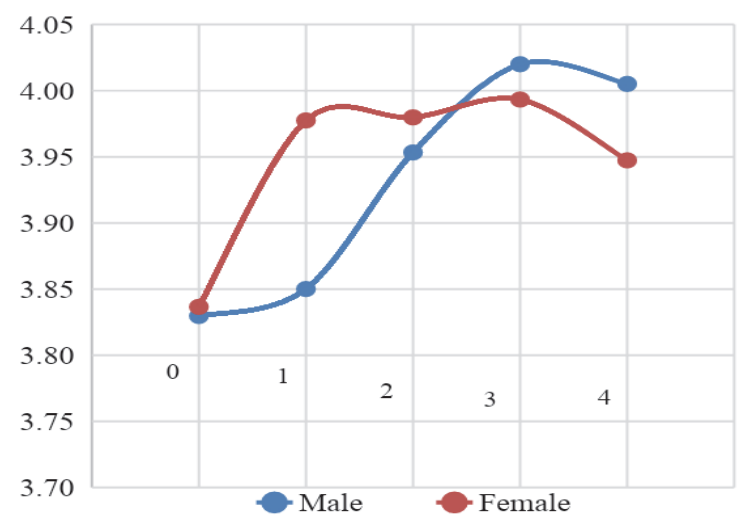

5b. Age

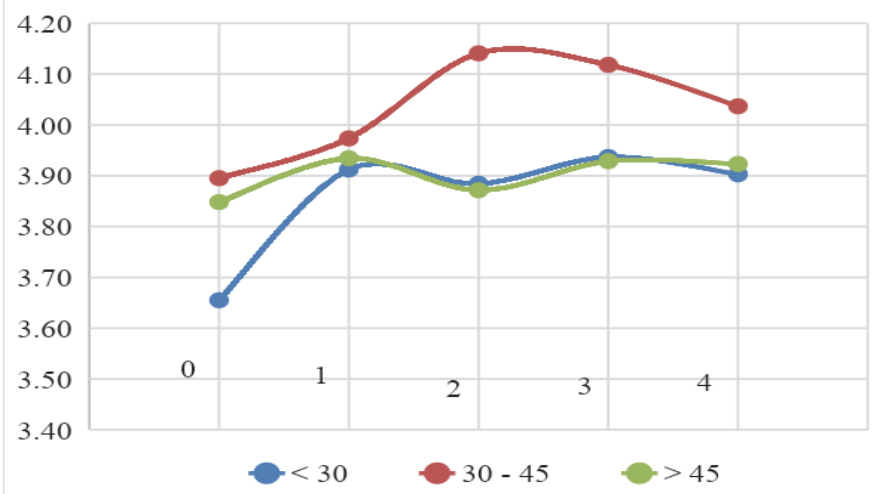

5c. Level of education

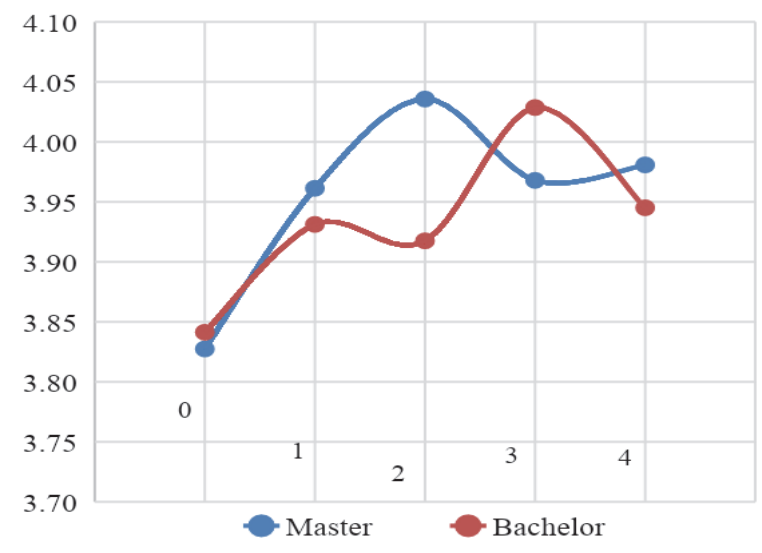

5d. Position

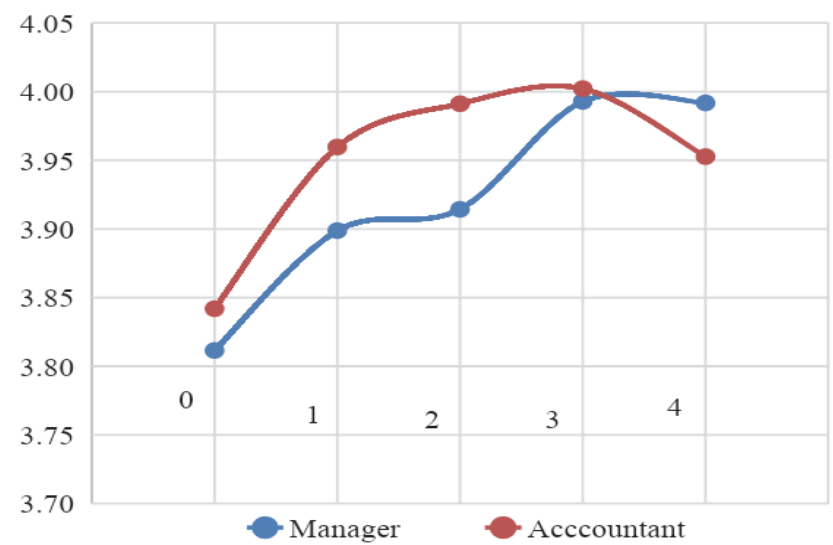

Fig. 5. Demographic comparison

(Source: Authors synthesized on the basis of research results)

Figs. 5a, 5b, 5c, and 5d show the results of the benefits and challenges by gender, age, education level, and job position (Figure 5). The data shows that there is basically no significant difference among the above groups, the mean values are 3.66 or higher, which indicates the consent of the respondents regarding the survey content. Specifically: 
The comparison by gender in figure 5a shows that there is not much of a difference in mean values of benefits and challenges between men and women with the mean values from 3.83-4.02. There is the largest difference between men and women regarding the benefits for investors, particularly, the mean value of female respondents is higher than that of male respondents (mean 3.98 versus 3.92). In general, the level of variation in the evaluation results of men is higher than that of women. This implies the general trend of Vietnam is that women often work in stable jobs like accountants, while job opportunities for men are more diversified. Therefore, their views, opinions and assessments are different. In terms of age, respondents under 30 and over 45 years old have similar assessments and respondents from 30 to 45 years old have a higher evaluation, both in terms of benefits and challenges, especially benefits for policy makers and authorities. The results show the general trend that younger age group ( $<30$ years) have less time for studying because they are in the stage of building a balance between stable family, work and finance. With people more than 45 years old, the ability and learning opportunities are lower, especially the lower ability to improve knowledge, access changes, and evaluate problems. Therefore, both groups have similar assessment results. However, respondents from 30 to 45 years old are the main labor force group. They have opportunities for studying, research, improving proficiency and adapting to changes. For this reason, their evaluation results are the highest on these factors. Comparison based on level of education in Fig. 5c shows that there is no significant difference in mean values of benefits and challenges of IFRS implementation between respondents who hold a bachelor's degree and one who hold a master's degree, mean values from 3.83 to 4.04. Particularly, regarding the benefits of IFRS implementation for policy makers, the mean value of people holding a master's degree is higher than that of people holding a bachelor's degree. On the contrary, regarding the benefits for managers, respondents who hold a bachelor's degree have higher mean value than that of people holding a master's degree. This result shows specific characteristics of Vietnamese enterprises. In Vietnamese enterprises, there is no difference regarding the qualifications when calculating salaries or development opportunities. Evaluation of enterprises depends on the individual performance. Therefore, there is no difference regarding benefits and challenges of IFRS implementation by level of education. The Fig. 5d compares between accountants and managers. The mean value of benefits of IFRS implementation of accountants is higher than that of directors, while the mean value of challenges of IFRS implementation of directors is higher than that of accountants. It can be explained by the fact that accountants directly do research to implement IFRS, thus, they thoroughly and fully evaluate the benefits for enterprises, investors as well as government agencies. On the other hand, managers are affected by reservation principle, in their assessment of benefits, because they themselves have not approached the IFRS in practice. Additionally, managers take legal responsibility, so challenges of the IFRS implementation receive more concern from managers.

\section{Comparison based on characteristics of enterprises}

Characteristics of the surveyed enterprises include age, business sector, type of business, geographic area and enterprise size (Fig. 6).
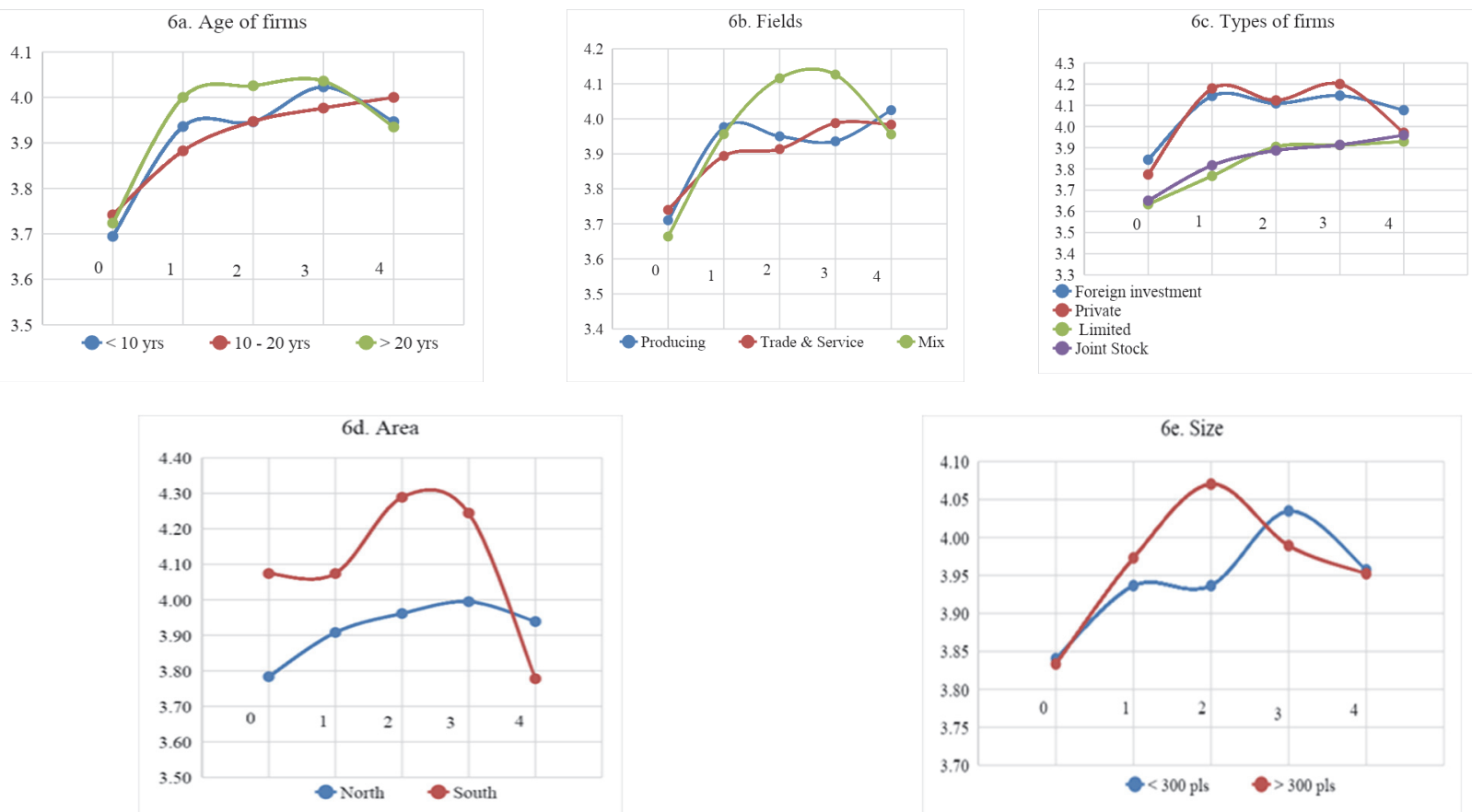

Fig. 6. Enterprise characteristics comparison (Source: Authors synthesized on the basis of research results) 
Figs. $6 \mathrm{a}, 6 \mathrm{~b}, 6 \mathrm{c}, 6 \mathrm{~d}$, and $6 \mathrm{e}$ show results of the benefits and challenges of IFRS implementation according to enterprise characteristics. The data shows that there is basically no significant difference by enterprise characteristics, the mean values were around 3.78, this indicate the consent of the respondents about the survey contents. Specifically:

Considering the age of the enterprise, the assessments of benefits and challenges of applying IFRS among groups of enterprises are relatively similar (mean values from 3.7 to 4.0). Enterprises which had been operating over 20 years assessed the benefits slightly higher and assessed the challenges slightly lower than that of other groups (6a). In this research sample, most enterprises which had been operating for over 20 years are joint stock companies or state-owned enterprises that have been equitized, or have operated independently or have followed the model of parent companies and subsidiaries. These are large enterprises with long histories, stable markets, stable production lines, and stable human resources so challenges are assessed lower than that of other groups. For enterprises with 10-20 years of operation, the evaluation results are the most stable. Enterprises which had been operating less than 10 years had unstable assessment results in both benefits and difficulties of IFRS implementation. In terms of business sector in Fig. 6b, there are 3 groups: manufacturing, trading and services, and mixed sectors. All three sectors have the same results of the assessment of benefits for enterprises (BEN), benefits for investors (BIN) and challenges (CHA).

The assessments of the benefits to policy makers (BPO) and the benefits for the authorities (BAU) of the enterprises in mixed sectors are higher than that of enterprises in the other sectors. Considering the type of enterprise (Fig. 6c), 4 types of enterprises are divided into 2 groups: Group 1 includes private enterprises and foreign-invested enterprises. This group does not depend on the capital and direct management of the government, therefore, their operating procedures and mechanisms are flexible and effective; Group 2 includes limited liability companies and joint stock companies. This group includes State-owned companies which are equitized, and private joint stock enterprises. One characteristic of this group is complexity of the system and operating mechanism. The characteristics of each group can influence the evaluation results. Particularly, the results show that there are significant similarities in each group and there are significant differences between the two groups. Specifically, group 1 assessed the benefits and challenges higher than group 2. Benefits for policy makers (BPO) had the highest mean value of 4.16; which is followed by the benefits for investors (BIN) with mean value of 4.10, and benefits for the authorities (BAU) with mean value of 4.12. In group 2, the figures were 3.90; 3.75 and 3.85 respectively. Regarding geographic area, there are significant differences among groups. The mean value of the benefits of enterprises in the South is higher than that of enterprises in the North. On the contrary, the mean value of challenges of enterprises in the North is higher than that of enterprises in the South. This result shows the specific characteristics and significant differences between two regions (the South and the North) of Vietnam. People in the South tend to be flexible in approaching new issues, learning foreign languages more due to the geographical location adjacent to Cambodia, Malaysia, Brunei, Singapore. People in the North tend to be rigid, inflexible, with worse English proficiency due to geographical location adjacent to China, Laos, Thailand which are non-English speaking countries. In terms of enterprise size, there is no clear trend in the evaluation between SMEs and large enterprises. The evaluations are similar regarding the benefits for enterprises (BEN) and challenges (CHA). There are differences in benefits for policy makers (BPO), particularly assessment of large enterprises is higher than SMEs. The data from the figure shows that there is no difference in benefits and challenges of each control variable. To draw specific conclusions, Sample Test analysis is conducted.

\subsection{Analysis and comparison with t-test}

\section{Comparison based on demographic characteristics}

\section{Comparison between male and female respondents}

Regarding the benefits for enterprises (BEN) in Table 5, the F-test had a significance value of $0.144>0.05$, so there is no difference in the variance of the 2 groups. The results in Equal variances assumed shows that significance value $=0.947>0.05$, therefore, there is no significant difference in the mean value between male and female respondents. Thus, there is no difference in the benefits for enterprises between men and women.

In terms of the benefits for investors (BIN), the above table shows that the F-test had a significance value of $0.028<0.05$, there are differences in the variance of the 2 groups. The results in the Equal not variances assumed shows that significance value $=$ $0.341>0.05$, therefore, there is no significant difference in the mean value between male and female respondents. Thus, there is no difference in the benefits for investors between men and women.

Regarding the benefits for policy makers (BPO), the F-test had a significance value of $0.069>0.05$, there is no difference in the variance of the 2 groups. The results in Equal variances assumed shows that significance value $=0.826>0.05$, thererefore, there is no significant difference in the mean value between male and female respondents. Thus, there is no difference in the benefits for policy makers between men and women.

In terms of the benefits for authorities (BAU), the above table shows that the F-test has a significance value of $0.080>0.05$, 
there is no difference in the variance of the 2 groups. The results in the Equal not variances assumed shows that significance value $=0.815>0.05$, therefore, there is no significant difference in the mean value between male and female respondents. Thus, there is no difference in the benefits for authorities between men and women.

Table 3

Independent Samples Test_Demographic

\begin{tabular}{|c|c|c|c|c|c|c|c|c|c|c|}
\hline & & \multicolumn{3}{|c|}{ Gender } & \multicolumn{3}{|c|}{ Level of education } & \multicolumn{3}{|c|}{ Job position } \\
\hline & & \multicolumn{2}{|c|}{$\begin{array}{c}\text { Levene's Test for } \\
\text { Equality of } \\
\text { Variances } \\
\end{array}$} & $\begin{array}{l}\text { t-test for } \\
\text { Equality of } \\
\text { Means } \\
\end{array}$ & \multicolumn{2}{|c|}{$\begin{array}{l}\text { Levene's Test for } \\
\text { Equality of Variances }\end{array}$} & $\begin{array}{l}\text { t-test for } \\
\text { Equality of } \\
\text { Means } \\
\end{array}$ & \multicolumn{2}{|c|}{$\begin{array}{c}\text { Levene's Test } \\
\text { for Equality of } \\
\text { Variances }\end{array}$} & \multirow{2}{*}{$\begin{array}{l}\text { t-test for } \\
\text { Equality of } \\
\text { Means }\end{array}$} \\
\hline & & $\mathrm{F}$ & Sig. & Sig. (2-tailed) & $\mathrm{F}$ & Sig. & Sig. (2-tailed) & $\mathrm{F}$ & Sig. & \\
\hline \multirow{2}{*}{ BEN } & Equal variances assumed & $\begin{array}{r}2.16 \\
3\end{array}$ & 0.144 & 0.947 & 0.017 & 0.895 & 0.875 & $\begin{array}{r}1.56 \\
6\end{array}$ & 0.213 & 0.771 \\
\hline & $\begin{array}{l}\text { Equal variances not } \\
\text { assumed }\end{array}$ & & & 0.949 & & & 0.876 & & & 0.79 \\
\hline \multirow{2}{*}{ BIN } & Equal variances assumed & $\begin{array}{r}4.94 \\
7\end{array}$ & 0.028 & 0.262 & 0.231 & 0.632 & 0.762 & $\begin{array}{r}1.95 \\
6\end{array}$ & 0.165 & 0.602 \\
\hline & $\begin{array}{l}\text { Equal variances not } \\
\text { assumed }\end{array}$ & & & 0.341 & & & 0.762 & & & 0.656 \\
\hline \multirow{2}{*}{ BPO } & Equal variances assumed & $\begin{array}{r}3.35 \\
8\end{array}$ & 0.069 & 0.826 & 0.103 & 0.748 & 0.258 & $\begin{array}{r}2.17 \\
2\end{array}$ & 0.143 & 0.533 \\
\hline & $\begin{array}{l}\text { Equal variances not } \\
\text { assumed }\end{array}$ & & & 0.839 & & & 0.258 & & & 0.569 \\
\hline \multirow{2}{*}{ BAU } & Equal variances assumed & $\begin{array}{r}3.12 \\
9\end{array}$ & 0.08 & 0.815 & 0.064 & 0.8 & 0.542 & $\begin{array}{r}1.06 \\
6\end{array}$ & 0.304 & 0.936 \\
\hline & $\begin{array}{l}\text { Equal variances not } \\
\text { assumed }\end{array}$ & & & 0.832 & & & 0.542 & & & 0.942 \\
\hline \multirow{2}{*}{$\mathrm{CHA}$} & Equal variances assumed & $\begin{array}{r}2.27 \\
7\end{array}$ & 0.134 & 0.511 & 0.215 & 0.644 & 0.641 & $\begin{array}{r}0.18 \\
3\end{array}$ & 0.669 & 0.664 \\
\hline & $\begin{array}{l}\text { Equal variances not } \\
\text { assumed }\end{array}$ & & & 0.561 & & & 0.64 & & & 0.653 \\
\hline
\end{tabular}

(Source: Authors synthesized on the basis of research results)

In terms of the challenges of the IFRS implementation (CHA), the above table shows that the F-test had a significance value of $0.134>0.05$, there is no difference in the variance of the 2 groups. The results in the Equal not variances assumed shows that significance value $=0.511>0.05$, therefore, there is no significant difference in the mean value between male and female respondents. Thus, there is no difference in the challenges of the IFRS implementation between men and women.

The comparison between men and women shows that there is no difference regarding the benefits and challenges of IFRS implementation in Vietnam. This can be explained by the fact that there is implementation of gender equality in Vietnam. Man and woman are trained equally in schools, with the same employment opportunities and promotion opportunities. Therefore, men and women have the same rights and obligations at the workplace. In this research sample, although the majority of respondents are female, there is no difference in the benefits and challenges of IFRS implementation between men and women.

\section{Comparison based on level of education}

The above table shows that the F-test has Significance values varies from 0.632 to $0.895>0.05$ which means there is no difference in the variance of the 2 groups. The results in the Equal not variances assumed shows that all significance values are greater than 0.05 , therefore, there is no significant difference in the mean value between 2 groups. Thus, there is no difference in the benefits and challenges of IFRS implementation between people who have a bachelor's degree and people who hold a master's degree. In this research sample, there is only two groups of the respondents regarding the educational level: bachelor's degree and master's degree. However, the assessment of benefits and challenges of IFRS implementation is similar between two groups. This can be explained by the fact that salary is paid according to job position if it is a joint stock company, and the salary is calculated according to workplace tenure. Therefore, a bachelor's degree or a master's degree does not affect the salary and work. Therefore, their assessments are not significantly different.

\section{Comparison based on position}

In the above table, the F-test has Significance values ranging from 0.143 to $0.669>0.05$ which means there is no difference in the variance between two groups. The results of Equal variances assumed shows that all significance values are greater than 0.05 , therefore, there is no significant in the mean values of 2 groups. There is no difference in the benefits and challenges of 
the implementation of IFRS between the two groups of managers and accountants.

\section{Comparison based on the characteristics of enterprises}

\section{Table 4}

Independent Samples Test_Firms

\begin{tabular}{|c|c|c|c|c|c|c|c|}
\hline & & \multicolumn{3}{|c|}{ Area } & \multicolumn{3}{|c|}{ Size } \\
\hline & & \multicolumn{2}{|c|}{$\begin{array}{c}\text { Levene's Test for Equality } \\
\text { of Variances }\end{array}$} & \multirow{2}{*}{$\begin{array}{l}\text { t-test for Equality of } \\
\text { Means } \\
\text { Sig. (2-tailed) }\end{array}$} & \multicolumn{2}{|c|}{$\begin{array}{c}\text { Levene's Test for Equality of } \\
\text { Variances }\end{array}$} & \multirow{2}{*}{$\begin{array}{l}\text { t-test for Equality } \\
\text { of Means }\end{array}$} \\
\hline & & $\mathrm{F}$ & Sig. & & $\mathrm{F}$ & Sig. & \\
\hline \multirow{2}{*}{ BEN } & Equal variances assumed & 1.274 & 0.262 & 0.076 & 3.959 & 0.049 & 0.942 \\
\hline & Equal variances not assumed & & & 0.013 & & & 0.948 \\
\hline \multirow{2}{*}{ BIN } & Equal variances assumed & 0.939 & 0.335 & 0.349 & 0.539 & 0.465 & 0.738 \\
\hline & Equal variances not assumed & & & 0.187 & & & 0.744 \\
\hline \multirow{2}{*}{$\mathrm{BPO}$} & Equal variances assumed & 0.352 & 0.554 & 0.065 & 0.033 & 0.855 & 0.233 \\
\hline & Equal variances not assumed & & & 0.018 & & & 0.225 \\
\hline \multirow{2}{*}{ BAU } & Equal variances assumed & 0.214 & 0.645 & 0.133 & 2.798 & 0.098 & 0.665 \\
\hline & Equal variances not assumed & & & 0.127 & & & 0.645 \\
\hline \multirow{2}{*}{ CHA } & Equal variances assumed & 0.167 & 0.684 & 0.249 & 0.172 & 0.679 & 0.947 \\
\hline & Equal variances not assumed & & & 0.279 & & & 0.948 \\
\hline
\end{tabular}

(Source: Authors synthesized on the basis of research results)

\section{Comparison based geographic area}

In Table 4, the F-tests has all significance values $>0.05$ which means there is no difference in the variance between two groups. The results of Equal variances assumed show that all significance value are greater than 0.05 , therefore, there is no significant difference in the mean values of 2 groups. Thus, there is no difference in the benefits and challenges of the implementation of IFRS between enterprises in the North and the South.

\section{Comparison based on enterprise size}

In the above table, the F-tests has significance value of $0.0049<0.05$ which means there is difference in the variance between two groups. The results of Equal variances assumed shows that the significance value is $0.948>0.05$, therefore, there is no significant difference in the mean values of 2 groups. Thus, there is no difference in the benefits of the implementation of IFRS between medium-sized enterprises and large enterprises. Additionally, there is no difference in the benefits for investors and policy makers, and challenges of IFRS implementation between two groups of enterprises.

\subsection{ANOVA analysis}

The Anova analysis is conducted with age groups (age of respondents and age of the enterprise); business sectors; types of enterprises, the results show that there is difference between the age of the respondents and the business sector of the enterprises. The results are explained as follows:

Comparison based on age of respondents

Table 5a

Test of Homogeneity of Variances_Age

\begin{tabular}{lcccc}
\hline & Levene Statistic & df1 & df2 & Sig. \\
\hline BEN & 1.187 & 2 & 116 & .309 \\
BIN & .229 & 2 & 116 & .796 \\
BPO & .757 & 2 & 116 & .471 \\
BAU & 1.289 & 2 & 116 & .280 \\
CHA & .082 & 2 & 116 & .921 \\
\hline
\end{tabular}

(Source: Authors synthesized on the basis of research results)

- In Table 5a, the Test of Homogeneity of Variances shows that all significance values are greater than 5\%, therefore, there is no difference in variance between groups and data is appropriate for ANOVA analysis. The results of Levene test shows that all significance values are greater than 0.1 , thus there is no difference in variance between groups. The ANOVA analysis results are shown in Table $5 b$. 
Table 5b

ANOVA_Age

\begin{tabular}{|c|c|c|c|c|c|c|}
\hline & & Sum of Squares & $\mathrm{df}$ & Mean Square & $\mathrm{F}$ & Sig. \\
\hline \multirow{3}{*}{$\mathrm{BEN}$} & Between Groups & .276 & 2 & .138 & .544 & .582 \\
\hline & Within Groups & 29.381 & 116 & .253 & & \\
\hline & Total & 29.656 & 118 & & & \\
\hline \multirow{3}{*}{$\mathrm{BIN}$} & Between Groups & .062 & 2 & .031 & .106 & .899 \\
\hline & Within Groups & 33.944 & 116 & .293 & & \\
\hline & Total & 34.006 & 118 & & & \\
\hline \multirow{3}{*}{$\mathrm{BPO}$} & Between Groups & 1.968 & 2 & .984 & 3.168 & .046 \\
\hline & Within Groups & 36.026 & 116 & .311 & & \\
\hline & Total & 37.994 & 118 & & & \\
\hline \multirow{3}{*}{ BAU } & Between Groups & .976 & 2 & .488 & 1.702 & .187 \\
\hline & Within Groups & 33.264 & 116 & .287 & & \\
\hline & Total & 34.240 & 118 & & & \\
\hline \multirow{3}{*}{ CHA } & Between Groups & .397 & 2 & .198 & 1.160 & .317 \\
\hline & Within Groups & 19.850 & 116 & .171 & & \\
\hline & Total & 20.247 & 118 & & & \\
\hline
\end{tabular}

(Source: Authors synthesized on the basis of research results)

-The ANOVA analysis (Table 5b) shows that BPO has a significance value of $0.046<5 \%$, which indicates that there is difference in the benefits for investors among age groups. Other variables BEN, BIN, BAU, CHA have significance values greater than 0.05 , therefore, there is no difference in the mean values between age groups. Therefore, in this study, there is not enough evidence to confirm the difference in the benefits for enterprises, investors and authorities, and challenges of IFRS implementation between age groups.

Table 5c

Multiple Comparisons_Age

\begin{tabular}{|c|c|c|c|c|c|c|c|}
\hline \multirow{2}{*}{$\begin{array}{l}\text { LSD } \\
\text { Dependent } \\
\text { Variable }\end{array}$} & \multirow[t]{2}{*}{ (I) Age } & \multirow[t]{2}{*}{ (J) Age } & \multirow{2}{*}{$\begin{array}{c}\text { Mean } \\
\text { Difference (I-J) }\end{array}$} & \multirow[t]{2}{*}{ Std. Error } & \multirow[t]{2}{*}{ Sig. } & \multicolumn{2}{|c|}{$95 \%$ Confidence Interval } \\
\hline & & & & & & Lower Bound & Upper Bound \\
\hline \multirow{6}{*}{$\mathrm{BPO}$} & \multirow{2}{*}{$<30$} & $30-45$ & -.25670 & .15298 & .096 & -.5597 & .0463 \\
\hline & & $>45$ & .01278 & .14796 & .931 & -.2803 & .3058 \\
\hline & \multirow{2}{*}{$30-45$} & $<30$ & .25670 & .15298 & .096 & -.0463 & .5597 \\
\hline & & $>45$ & $.26948^{*}$ & .11227 & .018 & .0471 & .4918 \\
\hline & \multirow{2}{*}{$>45$} & $<30$ & -.01278 & .14796 & .931 & -.3058 & .2803 \\
\hline & & $30-45$ & $-.26948^{*}$ & .11227 & .018 & -.4918 & -.0471 \\
\hline
\end{tabular}

*. The mean difference is significant at the 0.05 level.

(Source: Authors synthesized on the basis of research results)

- Table 5c shows the Post Hoc Tests Multiple Comparisons. BPO has a significance value of $0.018<0.05$ when comparing the group of 30-45 year old and the group of over 45 years old. This means that among the 3 age groups, there is difference in the benefits for policy makers in these two groups. The Mean Difference (I-J) is $0.26948 *$, which indicates that mean value of satisfaction of the group of 30-45 year old is higher than that of the group of over 45 years old. In other words, there is a significant difference in the benefits for policy makers between the group of over 45 years old and the age group of 30-45 year old.

\section{Comparison based on types of enterprises}

The Significance values of BEN, BIN, BPO, BAU, CHA are greater than 0.05, therefore, hypothesis Ho is accepted (heterogeneous variance), the data is appropriate for ANOVA analysis (table 6a).

Table 6a

Test of Homogeneity of Variances_Types of firms

\begin{tabular}{lcccc}
\hline & Levene Statistic & df1 & df2 & Sig. \\
\hline BEN & .236 & 3 & 86 & .871 \\
BIN & .516 & 3 & 86 & .673 \\
BPO & .672 & 3 & 86 & .571 \\
BAU & 1.745 & 3 & 86 & .164 \\
CHA & .444 & 3 & 86 & .722 \\
\hline
\end{tabular}

(Source: Authors synthesized on the basis of research results) 
- The ANOVA analysis (6b), BIN has significance value of $0.018<0.05$, this indicates that there is difference in the benefits for investors between types of enterprises. BEN, BPO, BAU, CHA have significance values greater than 0.05 , therefore, there is no difference in the benefits and challenges of IFRS implementation between age groups.

Table 6b

ANOVA_Types of firms

\begin{tabular}{|c|c|c|c|c|c|c|}
\hline & & Sum of Squares & df & Mean Square & $\mathrm{F}$ & Sig. \\
\hline \multirow{3}{*}{ BEN } & Between Groups & .699 & 3 & .233 & 1.158 & .331 \\
\hline & Within Groups & 17.304 & 86 & .201 & & \\
\hline & Total & 18.003 & 89 & & & \\
\hline \multirow{3}{*}{ BIN } & Between Groups & 2.866 & 3 & .955 & 3.537 & .018 \\
\hline & Within Groups & 23.228 & 86 & .270 & & \\
\hline & Total & 26.094 & 89 & & & \\
\hline \multirow{3}{*}{$\mathrm{BPO}$} & Between Groups & 1.038 & 3 & .346 & 1.192 & .318 \\
\hline & Within Groups & 24.966 & 86 & .290 & & \\
\hline & Total & 26.004 & 89 & & & \\
\hline \multirow{4}{*}{ BAU } & Between Groups & 1.393 & 3 & .464 & 1.982 & .123 \\
\hline & Within Groups & 20.156 & 86 & .234 & & \\
\hline & Total & 21.549 & 89 & & & \\
\hline & Between Groups & .285 & 3 & .095 & .705 & .552 \\
\hline \multirow[t]{2}{*}{$\mathrm{CHA}$} & Within Groups & 11.612 & 86 & .135 & & \\
\hline & Total & 11.897 & 89 & & & \\
\hline
\end{tabular}

(Source: Authors synthesized on the basis of research results)

- Table 6c shows Post Hoc Tests Multiple Comparisons. The results show that there is difference in the benefits for investors between types of enterprises with $95 \%$ confidence, specifically:

- Foreign-invested enterprises versus limited liability enterprises had a significance value of $0.015<0.05$, Difference is $0.37727^{*}$. This shows that benefits for investors are rated higher by foreign-invested enterprises than by limited liability enterprises.

- Foreign-invested enterprises versus joint stock enterprises had a significance value of $0.027<0.05$, Difference is $0.32727^{*}$. This shows that benefits for investors are rated higher by foreign-invested enterprises than by joint stock enterprises.

- Privately-owned enterprises versus limited liability enterprises had a significance value of $0.023<0.05$, Difference is $0.41282^{*}$. This shows that benefits for investors are rated higher by privately-owned enterprises than by limited liability enterprises.

- Privately-owned enterprises versus joint stock enterprises had a significance value of $0.038<0.05$, Difference is $0.36282^{*}$. This shows that benefits for investors are rated higher by privately-owned enterprises than by joint stock enterprises.

Table 6c

Multiple Comparisons_Types of firms

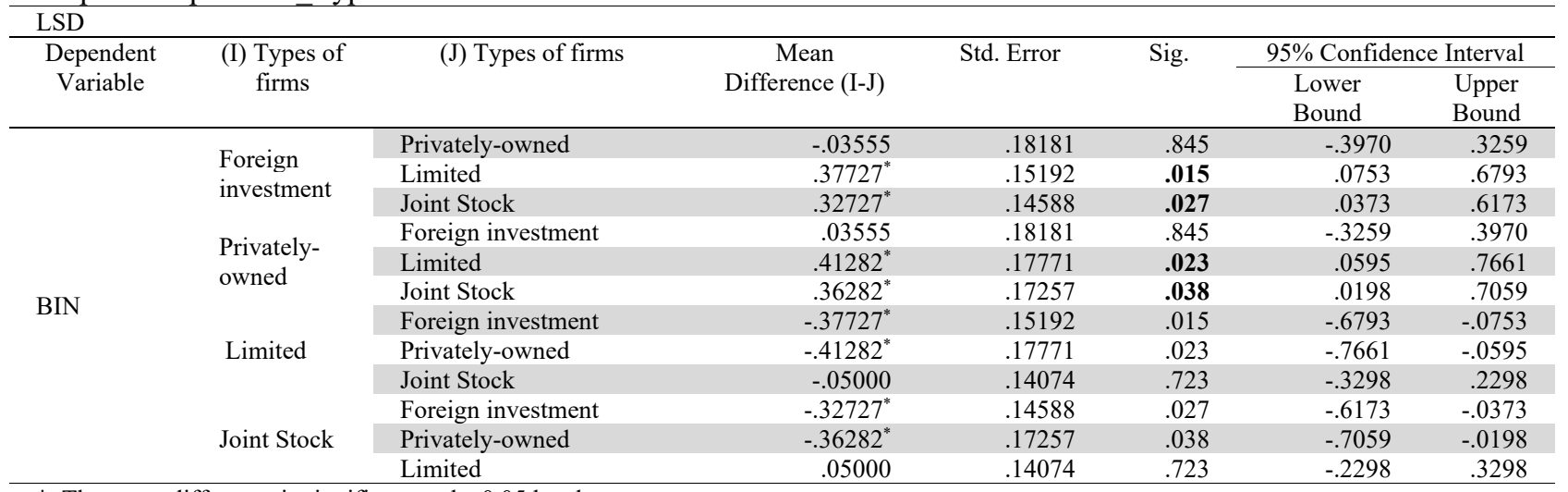

*. The mean difference is significant at the 0.05 level.

(Source: Authors synthesized on the basis of research results)

As mentioned in Fig. 6c, foreign-invested enterprises and privately-owned enterprises are classified into group 1. This group does not depend on capital and direct management of the government; therefore the operating procedures are flexible and effective. They have autonomy regarding capital, human resources, procedures, and applying new advances to work, therefore, the efficiency will be higher than the remaining groups of enterprises. 
The results have shown that the application of IFRS can bring many benefits to enterprises, investors, policy makers and authorities. Particularly, the benefits for enterprises are most appreciated, which is followed by benefits for authorities. This result is consistent with previous studies on the benefits of IFRS application: (i) Improving the quality of financial statements and corporate management Merve et al. (2014), Uyar \& Güngörmüş (2013); (ii) Attracting domestic and foreign investment of individuals and organizations Joshi et al. (2016), John (2018), Herath \& Alsulmi (2017); (iii) Improving the effectiveness of control and reduce audit costs Joshi et al. (2016), Kiliçaa (2014); (iv) Improving competitiveness and facilitating easier accounting work for John (2018), Adejoh (2014), Odia (2013). Research in Vietnam also provided the similar benefit of IFRS implementation that it helps to make financial information more transparent (KPMG Vietnam, 2018), Tu Chuc Anh et al. (2019).

For state management agencies, the application of IFRS brings useful information for decision making, administration, risk control, inspecting and supervising State enterprises. Previous researches also showed that IFRS requires enterprises to enhance transparency of the financial statements and the ability to compare between businesses, helping the state management agencies make requirements for financial information presentation, control according to the standards of financial disclosure (DeFond et al., 2011; Bhattacharjee, 2010; John, 2018; Herath \& Alsulmi, 2017).

Regarding the challenges of IFRS implementation, the majority of the respondents stated that the biggest difficulties were market problems. Because IFRS requires fair value recognition, while capital and financial markets are developing, it is impossible to get reliable information about fair value and many transactions are difficult to identify because different markets are not synchronized. KPMG Vietnam (2018) also received a consensus from in-depth interviews with 27 enterprises who supposed that the first implementation of IFRS would be expensive. Tu Chuc Anh et al. (2019) showed that the application of IFRS is expensive in terms of training costs, hiring experts. Research by Tu Oanh et al. (2019) also pointed out one of the biggest difficulties when applying IFRS in Vietnam is the conversion cost.

The results of group comparison with Sample Test showed that there was no difference in the benefits and challenges of IFRS implementation by educational level, gender, position, region and enterprise size. ANOVA analysis showed that there was a difference in the benefits for policy makers by age group, there was a difference in the benefits for investors by type of enterprise.

The research results are an objective basis for the implementation of IFRS in Vietnam because of the expectation of benefits for enterprises and authorities. In order to widely implement IFRS in Vietnam, it is vital to have a macro strategy from the Government, the consensus of policy makers, managers, accountants and lecturers. Some recommendations to promote the IFRS application process and promote the benefits of IFRS application in Vietnam are proposed as follows:

Firstly, it is important to strengthen the dissemination and training of IFRS for experts, lecturers, auditors and accountants. For universities, it is necessary to strengthen the training and retraining about IFRS to produce competent and knowledgeable financial and accounting staff to apply IFRS in Vietnam. This is very important because IFRS is very complicated even for developed countries.

Secondly, it is necessary to reach a consensus about the role and significance of financial statements presented according to IFRS. It is necessary to propagandize and widely advertise in many ways so that managers, investors and accountants find it vital to present financial statements according to IFRS.

Thirdly, it is critical to complete mechanisms and policies for IFRS application in Vietnam. Additionally, it is necessary to develop regulations and guidelines for the implementation of some special IFRS techniques, such as recognition of loss on assets, accounting derivative instruments for hedging purposes, fair value accounting, investment in properties or biological assets. The implementation of IFRS is really a challenge on the level of development of the market, the qualifications and proficiency of auditors, accountants and investors in the market. For the capital market, stock market, preparing and presenting Financial Statements according to IFRS will help improve the transparency and sustainability of the market. However, preparing and presenting financial statements according to IFRS requires significant efforts from the government agencies in charge of accounting, enterprises, professional organizations and accountants.

\section{References}

Abd El Razik, A. (2014). Challenges of international financial reporting standards (IFRS) in the Islamic accounting world, case Middle Eastern Countries. Scientific Bulletin-Economic Sciences, 8(14), 1-6.

Aboagye-Otchere, F., \& Agbeibor, J. (2012). The International Financial Reporting Standard for Small and Medium- sized Entities (IFRS for SMES): Suitabitity for Small businesses in Ghana. Journal of Financial Reporting and Accounting, 10(2), Adejoh, E \& Hasnah, K. (2014). Adoption of international financial reporting standards in Nigeria: Concepts and issues. Journal of Advanced Management Science, 2(1), $72-75$

Agyei-Mensah, B. K. (2013). Adoption of International Financial Reporting Standards (IFRS) in Ghana and the quality of financial statement disclosures. International Journal of Accounting and Financial Reporting, 3, 269-286. 
Alkhtani, S. (2012). The relevance and usefulness of IFRSs to Saudi Arabia. Journal of Administrative and Economics Science, $5(2)$.

Atik, A. (2010) "SME's views on the adoption and application of "IFRS for SMEs" in Turkey". European Research Studies, 13(4), 19-31.

Artikis, G. P., Ballas, A. A., Skoutela, D., \& Tzovas, C. A. (2010). The relevance of IFRS to an emerging market: evidence from Greece. Managerial Finance.

Ashok, K. K. (2014). International financial reporting standard (IFRS): Prospects and challenges. J Account Mark, 3(111), 2.

Bhattacharjee, S., \& Hossain, M. S. (2010). Determinants of financial reporting outcomes following IFRS adoption-implications for Bangladesh. The Bangladesh Accountant, 69(40), 10-19, Retrieved 20 March 2017, from http://www.icab.org.bd/journal/61.pdf

Boateng, A. A., Arhin, A. B., \& Afful, V. (2014). International Financial Reporting Standard's (IFRS) adoption in Ghana: Rationale, benefits and challenges. Journal of Advocacy, Research and Education, 1(1), 26-32.

Bohušová, H., \& Blašková, V. (2011). In What Ways are Countries Which Have Already Adopted IFRS for SMEs Different. Acta Universitatis Agriculturae Et Silviculturae Mendelianae Brunensis, 4(2), 37-41.

Bunea, S., Săcarin, M. \& Minu, M. (2012). Romanian professional accountants' perception on the differential financial reporting for small and medium-sized enterprises. Accounting and Management Information Systems, 11(1), 27-43.

Chand, P., Patel, C. \& Patel, A. (2010) "Interpretation and application of "new" and "complex" international financial reporting standards in Fiji: Implications for convergence of accounting standards". Advances in Accounting, 26(2), 280-289.

Chen, H., Tang, Q., Jiang Y. \& Lin, Z. (2010). The role of international financial reporting standards in accounting quality: Evidence from the European Union. Journal of International Financial Management and Accounting 21(3), 56- 61.

Choi, F. D., \& Meek, G. K. (2011). International accounting. Pearson Higher Ed.

Daly, S. \& Frikha, M. (2015). Islamic Finance in Favor to Development and Economic Growth: An Illustration of the Principle of "Zakat". Arabian Journal of Business Management Review, 5, 145.

Cirkveni, T. (2011). Motifs and impediments for the harmonization of accounting regulations for small and medium-sized companies in the EU. Chinese Business Review, 10(11), 1021-1027.

Choi, J. S., \& Nam, J. A. (2020). Does managerial discretion affect the value relevance of goodwill impairment information under IFRS? Korean evidence. Asia-Pacific Journal of Accounting \& Economics, 27(1), 1-23.

DeFond, M., Hu, X., Hung, M., \& Li, S. (2011). The impact of mandatory IFRS adoption on foreign mutual fund ownership: The role of comparability. Journal of Accounting and Economics, 51(3), 240-258.

Dimitropoulos, E.P., Asteriou, D., Kousenidis, D \& Leventis, S. (2013). The impact of IFRS on accounting quality: Evidence from Greece. Advances in Accounting, 29(1), 108-123.

Gastón, S. C., García, C. F., Jarne, J. I. J., \& Gadea, J. A. L. (2010). IFRS adoption in Spain and the United Kingdom: Effects on accounting numbers and relevance. Advances in Accounting, 26(2), 304-313.

Girbina, M., Mihaela, M.I.N.U., Bunea, S., \& Sacarin, M. (2012). Perceptions of preparers from Romanian banks regarding IFRS application. Accounting and Management Information Systems, 11(2), 191-208.

Hail, L., Leuz, C. \& Wysocki, P. (2010). Global accounting convergence and the potential adoption of IFRS by the U.S. (Part I): Conceptual underpinnings and economics analysis. Accounting Horizons, 24, 355-394.

Herath, S. K., \& Alsulmi, F. H. (2017). International financial reporting standards (IFRS): The benefits, obstacles, and opportunities for implementation in Saudi Arabia. International Journal of Social Science and Business, 2(1), 1-18.

Joanne, H., George, S., \& Ioanna, S. (2016), Does mandatory IFRS adoption improve the information environment? https://doi.org/10.1111/j.1911-3846.2012.01159

John, O. O. (2018). Adoption of IFRS in Nigeria: Challenges and the way forward. International Journal of Academic Research in Business and Social Sciences, 8(8), $426-440$.

Joshi, M., Yapa, P. W. S., \& Kraal, D. (2016). IFRS adoption in ASEAN countries: perceptions of professional accountants from Singapore, Malaysia and Indonesia. Malaysia and Indonesia (January 4, 2016), 211-240.

Jones, S. \& Finley, A. (2011). Have IFRS made a difference to intra-country financial reporting diversity? British Accounting Review, 43(1), 22-38; https://doi.org/10.1016/j.bar.2010.10.004

Judge, W., Li, S., \& Pinsker, R. (2010) National adoption of international accounting standards: An institutional perspective. Corporate Governance: An International Review, 18(3), 161-174, https://doi.org/10.1111/j.1467-8683.2010.00798.

Kapoor, B., \& Ruhela, J. (2013). IFRS Implementation-Issues and Challenges for India. International Journal of Business and Management Research, 3(2), 103-106.

Kim, J. B., Tsui, J. S., \& Cheong, H. Y. (2011). The voluntary adoption of International Financial Reporting Standards and loan contracting around the world. Review of Accounting Studies, 16(4), 779-811.

Kiliçaa, M., Atamanc, B., \& Uyar, A. (2014). Preparedness for and perception of IFRS. Accounting and Management Information Systems, 13(3), 492.

KPMG Company Ltd. (2018), Report on the results of the Survey on the application of International Financial Reporting Standards in Vietnam, Appendix 02

Mihai, S., Ionaşcu, M., \& Ionaşcu, I. (2012). Economic benefits of International Financial Reporting Standards (IFRS) adoption 
in Romania: Has the cost of equity capital decreased? African Journal of Business Management, 6(1), 200-205.

Mohamed, Z. (2014). Challenges of International Financial Reporting Standards (IFRS) adoption in Libya. International Journal of Accounting and Financial Reporting, 4 (2), 390-412.

Monisola, O. (2013). Challenges of adoption of international accounting reporting standards in Nigeria: A counsel to Professional Accountants. Journal of Management Policy, 3(5), 10-31.

Mulyadi, M.S., Soepriyanto, G., \& Anwar, Y. (2012). IFRS adoption and taxation issue. International Journal of Artsand Commerce, 1(7), 159-165.

Nerudova, D., \& Bohusova, H. (2008). The empirical study of the SMEs position in the process of IFRS for SME application in the Czech Republic. Economics \& Management, 13, 163-169

Ocansey, E. O.N.D., \& Enahoro, J. A. (2014). Comparative study of the international financial reporting standard implementation in Ghana and Nigeria. European Scientific Journal (May 2014 ed.), 10(13), 529-546.

Odia, J.O., \& Ogiedu, K.O. (2013). IFRS Adoption: Issues, Challenges and Lessons for Nigeria and other Adopters. Mediterranean Journal of Social Sciences, 4(3), 389-399, https://doi.org/10.5901/mjss.2013.v4n3p389.

Oghogho, G., Raphael, I. A., \& Kingsley, O. O. (2016). Challenges of the implementation of IFRS in less developed and developing countries. Igbinedion University Journal of Accounting, 1.

Okpala, K. (2012). Adoption of IFRS and Financial Statements Effects: The Perceived Implications on FDI and Nigeria Economy. Australian Journal of Business and Management Research, 2 (5), [76-83], 83-83.

Oluku, M. D., \& Ojeka, S. (2011). The challenge of culture to international financial reporting standards convergence. Interdisciplinary Journal of Contemporary Research in Business, 2(12), 914-925

Owolabi, A., \& Iyoha, F. O. (2012). Adopting International Financial Reporting Standards (IFRS) in Africa: benefits, prospects and challenges. African Journal of Accounting, Auditing and Finance, 1(1), 77-86.

Raoudha, T. (2016). Are IFRS Harder to Implement for Emerging Economies, Compared to Developed Countries? A Literature Review, Journal of Modern Accounting and Auditing

Ritsumeikan, L. (2012). Culture and the globalization of the international financial reporting standards (IFRS) in developing countries. Journal of International Business Research, 11(S2), 31.

Samaha, K., \& Khlif, H. (2016). Adoption of and compliance with IFRS in developing countries: A synthesis of theories and directions for future research. Journal of Accounting in Emerging Economies, 6(1), 33-49.

Shima, K. M., \& Yang, D. C. (2012). Factors affecting the adoption of IFRS. International Journal of Business, 17(3), 276-298

Siaga, S.F (2012). Challenges to the adoption of International Financial Reporting Standards in Africa. International Journal of Research in Commerce and Management 3(1), 50-69.

Siam, W. Z., \& Rahahleh, M. Y. (2010). Implications of applying the international financial reporting standards (IFRSs) for small and medium-sized enterprises on the accounting environment in Jordan. Journal of Accounting, Business and Management (JABM), 17(2).

Sun, J., Cahan, S. F., \& Emanuel, D. (2011). How would the mandatory adoption of IFRS affect the earnings quality of US firms? Evidence from cross-listed firms in the US. Accounting Horizons, 25(4), 837-860.

Trabelsi, R. (2016). Are IFRS Harder to Implement for Emerging Economies Compared to Developed Countries? A Literature Review. Journal of Modern Accounting and Auditing, 12(1), 1-16.

$\mathrm{Tu}$ Oanh Le Thi, Ngoc Bui Thi, Tu Chuc Anh (2019), Benefits and Difficulties of Adopting IFRSS. International Journal of Innovation, Creativity and Change, 10(9), 205-225

Tu Chuc Anh, Ngoc Bui Thi, Oanh Le Thi Tu (2019), Relationship between experts and enterprises viewed via the IFRS application: An empirical study in Vietnam. Asian Economic and Financial Review, 9(8), 946-963,

Uyar, A. \& Güngörmüş, A.H. (2013). Perceptions and knowledge of accounting professionals on IFRS for SMEs: evidence from Turkey. Research in Accounting Regulation, 25, 77-87.

Vietnam, Ministry of Finance (2017), IFRSs documents training

Winney, K., Marshall, D., Bender, B., \& Swiger, J. (2010). Accounting globalization: roadblocks to IFRS adoption in the United States. Global Review of Accounting and Finance, 1(1), 167-178.

Young, S., \& Zeng, Y. (2015). Accounting comparability and the accuracy of peer-based valuation models. The Accounting Review, 90(6), 2571-2601.

Zakari, M. A. (2014). Challenges of International Financial Reporting Standards (IFRS) Adoption in Libya. International Journal of Accounting and Financial Reporting, 4(2), 390-412.

Zéghal, D., Chtourou, S. \& Sellami, Y.M. (2011). An analysis of the effect of mandatory adoption of IAS/IFRS on earnings management. Journal of International Accounting, Auditing and Taxation, 20(2), 61-72. 
(C) 2020 by the authors; licensee Growing Science, Canada. This is an open access article distributed under the terms and conditions of the Creative Commons Attribution (CC-BY) license (http://creativecommons.org/licenses/by/4.0/). 